\title{
Peter Tuleja
}

\section{ANALYSIS OF EXISTING DRIVE UNIT SOLUTIONS FOR THE PNEUMOBILE PROJECT}

Urgency of the research. Today, there is a need to provide alternative propulsion methods in the automotive industry. Compressed air is one of the alternatives to fossil fuels.

Target setting. To test the possibilities of using compressed air as energy for vehicle propulsion, a competition is organized, where teams from European universities are presented under the auspices of a company producing pneumatic components. We from the Institute of Automation, Mechatronics, Manufacturing Technology and Robotics also took part in this competition twice. The results of the competition, supplemented by the presentation of a vehicle not yet implemented, are the subject of this article.

Actual scientific researches and issues analysis. As this is an analysis of the results achieved, the article deals with the ways in which they were achieved rather than with methods of a scientific nature.

Uninvestigated parts of general matters defining. As this is an evaluation of the achieved results, the article does not address specific problems in the theoretical area. The results are presented for review by the reader and give room for his own assessment.

The research objective. The aim of the article is to acquaint the public with the results and the ways in which they were achieved. It is also a kind of invitation for potential people interested in this issue.

The statement of basic materials. The basis for the creation of the article was information from student works, the result of which were described vehicles.

Conclusions. The conclusions in the article show the problems that need to be solved for the further continuation of the project, if possible with other "enthusiasts" in the field using compressed air for non-traditional purposes.

Keywords: Pneumobile Project; analysis; parameters of pneumatic engine; pneumatic components.

Fig.: 8. Table: 4. References: 11.

Introduction. The previous issues of the magazine already mentioned the activities that were undertaken by our institute in the previous years of the Aventics/Emerson PNEUMOBILE Competition race. The competition since 2007 is traditionally organized in the Hungarian city of Eger. It takes place as a 3-day meeting of enthusiasts, at which individual teams from different European countries present their results in the construction of a vehicle whose propulsion is based on compressed air.

Variants of drive units. There are a relatively large number of variants of the vehicle drive unit construction [2]. In our performance so far in the competition, we have built 3 drive unit concepts. Two of them were confronted directly in the competition, the construction of the third was stopped by the situation around the coronavirus pandemic.

Since the competition regulations allow to build a drive unit exclusively with max. four linear single - piston pneumatic actuators (exclusively from AVENTICS, now part of EMERSON) PRA series [6], the solvers must look for a suitable mechanical variant of the transformation of a linear actuator into a rotary one.

The competition is divided into three separate races [1], the results of which are limited by certain conditions of the pneumatic and mechanical elements used. It is therefore necessary to determine their optimal arrangement so that the vehicle can drive as fast as possible and have sufficient acceleration with minimal air consumption.

Obstacles in this effort are the limited amount of compressed air, its compressibility, the rate of air consumption of individual components and their force effects. All in interaction, Fig. 1.

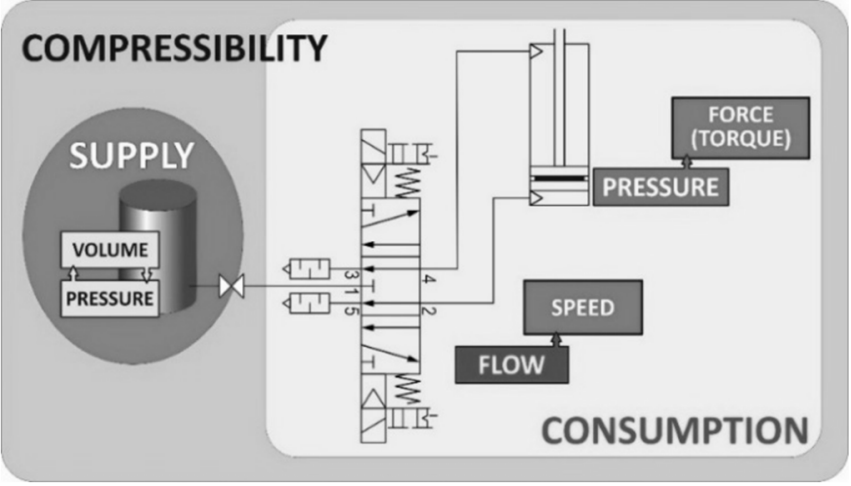

Fig. 1. Parameters influencing the construction of the drive unit

(C) Петер Тулея, 2020 
If we start from a precisely defined and non-renewable supply of compressed air $\left(10 \mathrm{dm}^{3}\right.$ of medium, in recent years $\mathrm{N}_{2}$ compressed to a pressure of $20 \mathrm{MPa}$ ) the course of loss of medium is obvious and at the end of pumping the supply also a gradual decrease of usable pressure.

The recalculated volume of air to a pressure value of $1 \mathrm{MPa}$ (the value of the max. pressure with which the vehicle drive can operate) is from Boyle's law (Boyle-Mariott's law):

$$
p_{1} \cdot V_{1}=p_{2} . V_{2}=\text { konst, teda } 20 \mathrm{MPa} .10 \mathrm{dm}^{3}=1 \mathrm{MPa} \cdot V_{2} \rightarrow V_{2}=20.10 \mathrm{dm}^{3}=200 \mathrm{dm}^{3} \text {. }
$$

Drive unit concepts. So far, three types of power units have been built. The first, Fig. 2, used a trio of pneumatic cylinders with a diameter of $100 \mathrm{~mm}$ and a stroke of $80 \mathrm{~mm}$, their arrangement being a star with an angular displacement of the cylinders of $120^{\circ}$. The torque was transmitted to the rear axle formed by one wheel.

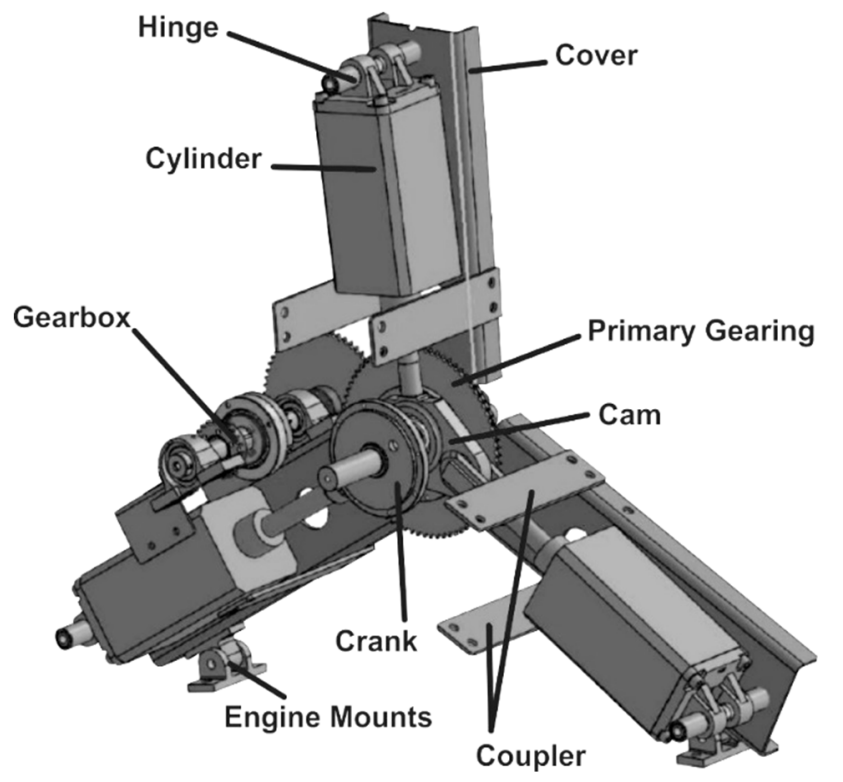

Fig. 2. Engine of the first vehicle [4] - modified by the author

The second version, Fig. 3, used two cylinders with a diameter of $100 \mathrm{~mm}$, but the stroke was $320 \mathrm{~mm}$, with both cylinders engaging independently of the rear driven axle via the rack and pinion mechanism and the interaction of the ratchet mechanism (only half of the drive unit is shown in Fig. 3).

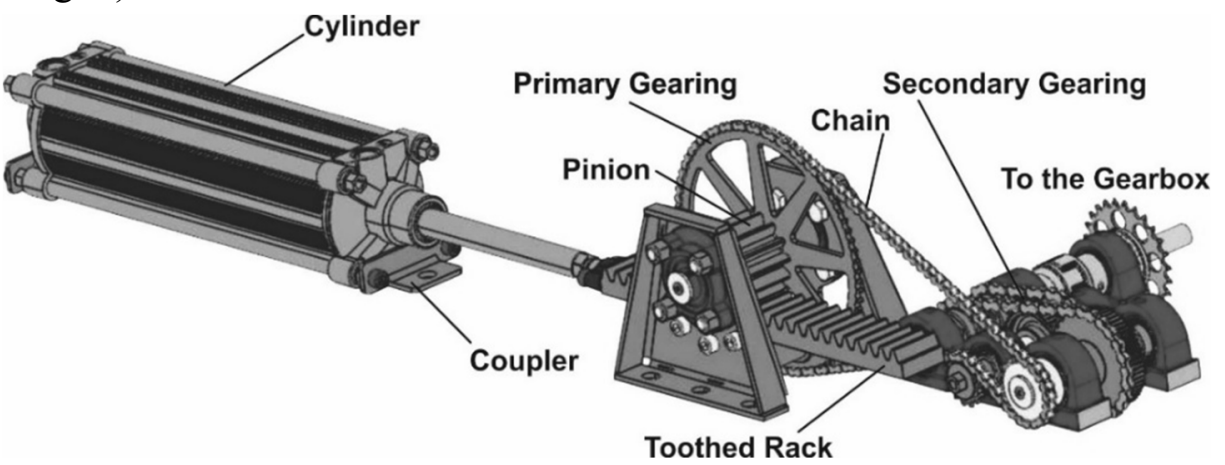

Fig. 3. Engine principle of the second vehicle [9] - modified by the author

The third version due to the COVID 19 pandemic has not yet been completed (work in progress approx. 65\%), Fig. 4. It uses a pair of cylinders with a diameter of $63 \mathrm{~mm}$ and a stroke of $320 \mathrm{~mm}$. The cylinders are coupled together at the end of their piston rods and fixed to a toothed belt. It engages in pulleys equipped with ratchet mechanisms, which ensures torque when moving in both directions. 


\section{TECHNICAL SCIENCES AND TECHNOLOGIES}

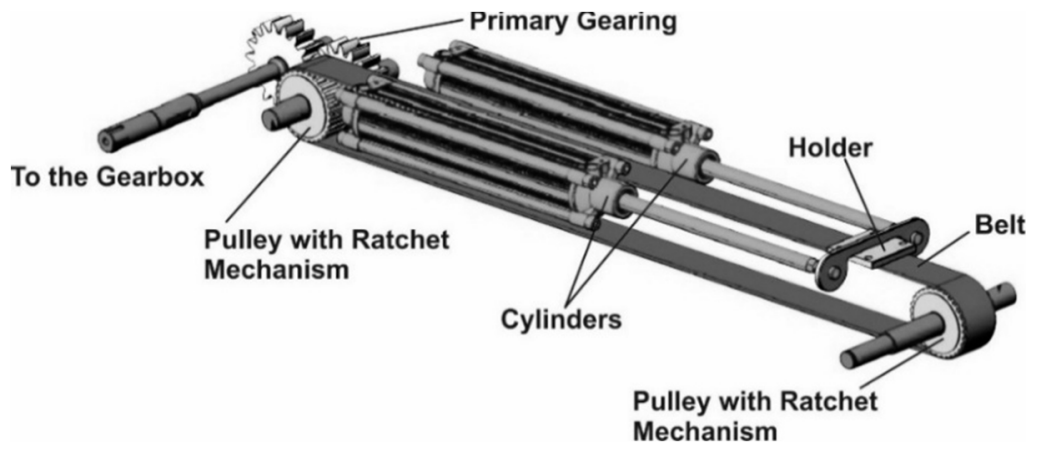

Fig. 4. Third vehicle engine principle (in preparation) [8] - modified by the author

From the point of view of vehicle characteristics, it is possible to evaluate individual versions as follows:

\section{Force characteristics}

Theoretical force of used actuators at different pressures:

Table 1

Theoretical forces of used pneumatic cylinders [N]

\begin{tabular}{|c|c|c|c|c|c|c|c|c|c|c|}
\hline $\begin{array}{c}\text { Piston } \\
\text { Diameter } \\
{[\mathrm{mm}]}\end{array}$ & \multicolumn{10}{|c|}{ Pressure $[\mathrm{MPa}]$} \\
\cline { 2 - 11 } & $\mathbf{0 , 1}$ & $\mathbf{0 , 2}$ & $\mathbf{0 , 3}$ & $\mathbf{0 , 4}$ & $\mathbf{0 , 5}$ & $\mathbf{0 , 6}$ & $\mathbf{0 , 7}$ & $\mathbf{0 , 8}$ & $\mathbf{0 , 9}$ & $\mathbf{1 , 0}$ \\
\hline $\mathbf{6 3}$ & 312 & 623 & 935 & 1247 & 1559 & 1870 & 2182 & 2494 & 2806 & 3117 \\
\hline $\mathbf{1 0 0}$ & 785 & 1571 & 2356 & 3142 & 3927 & 4712 & 5498 & 6283 & 7069 & 7854 \\
\hline
\end{tabular}

The efficiency of the drives is usually around $85-90 \%$. We present the theoretical strength and efficiency of the used cylinders only for information, because they do not give a picture of their use for the required torque. It strongly depends on the engine concept itself.

Torque characteristics

The torque on the output shaft of the drive unit is approximately $487 \mathrm{Nm}$ in the case of the 1 st vehicle, $122 \mathrm{Nm}$ in the case of the 2 nd vehicle and $253 \mathrm{Nm}$ (theoretically) in the case of the 3 rd vehicle.

\section{Achieved (expected) speeds}

The vehicle must reach a speed of at least $15 \mathrm{~km} / \mathrm{h}$, as this is a condition of the Long Distance competition. However, as the Acceleration Race is also run, it is usually higher. The results of vehicles in previous years are shown in tab. 2 . For the third vehicle that is being built with a view to placing in the Long Distance competition, the estimated speed is up to $20 \mathrm{~km} / \mathrm{h}$.

Table 2

Results of the Acceleration Race competition in the previous two years [10;11]

\begin{tabular}{|c|c|c|c|c|c|}
\hline Year & Place & Race No. & Team Name & Time & Speed \\
\hline 2019 & 16 & 16 & Air Force TUKE & 27.270 & 38.29 \\
\hline 2018 & 21 & 22 & TUKE SjF & 34.965 & 30.60 \\
\hline
\end{tabular}

\section{Air consumption}

As the supply of media is limited, this is one of the decisive criteria. The air consumption of a pneumatic drive is calculated from one double stroke of the drive, the total theoretical consumption of individual drive units is given in tab. 3 .

Table 3

Air consumption per double stroke of cylinder

\begin{tabular}{|c|c|c|c|c|c|}
\hline \multirow[b]{2}{*}{ Car } & \multirow[b]{2}{*}{$\begin{array}{c}\text { Diameter of } \\
\text { cylinder [mm] }\end{array}$} & \multirow[b]{2}{*}{$\begin{array}{c}\text { Cylinder stroke } \\
{[\text { [mm] }}\end{array}$} & \multirow[b]{2}{*}{$\begin{array}{c}\text { Number of } \\
\text { cylinders }\end{array}$} & \multicolumn{2}{|c|}{ Consumption } \\
\hline & & & & $\begin{array}{c}\text { of one cylinder } \\
{\left[\mathrm{dm}^{3}\right]}\end{array}$ & $\begin{array}{l}\text { Total } \\
{\left[\mathrm{dm}^{3}\right]}\end{array}$ \\
\hline 1 & 100 & 80 & 3 & 1.256638 & 5.654868 \\
\hline 2 & 100 & 320 & 2 & 5.026548 & 10.053096 \\
\hline 3 & 63 & 320 & 2 & 3.989698 & 7.979396 \\
\hline
\end{tabular}


However, these are only theoretical values. In order to determine the overall effect of propulsion in conjunction with other vehicle equipment, it is necessary to determine the movement characteristics of the vehicle by measurement (testing). The calculations involve determining gear ratios that determine the amount of travel traveled per stroke of the drive. While in the case of the engine of the first vehicle it is a gradual stroke of each of the engine cylinders to perform one revolution of the engine output shaft, for the other two drives this conversion is not applicable.

We therefore present the results documented in the competition, Tab. 4.

For the third vehicle in question, the estimated distance per bottle at an average speed of 15 $\mathrm{km} / \mathrm{h}$ is approximately $6 \mathrm{~km}$.

Table 4

Results of the Long Distance competition in previous years [10,11]

\begin{tabular}{|c|c|c|c|c|c|}
\hline Year & Place & Race No. & Team Name & Average Speed & Distance \\
\hline 2019 & 17 & 16 & Air Force TUKE & $16.690 \mathrm{~km} / \mathrm{h}$ & $3208 \mathrm{~m}$ \\
\hline 2018 & 15 & 22 & TUKE SjF & $14.509 \mathrm{~km} / \mathrm{h}$ & $3075 \mathrm{~m}$ \\
\hline
\end{tabular}

\section{Gearboxes}

Due to the performance characteristics of any air-powered mechanism, a suitable gearbox is also an important piece of equipment.

In the first vehicle, a simple $2^{\circ}$ gearbox controlled by a pair of pneumatic cylinders was used, Fig. 5.
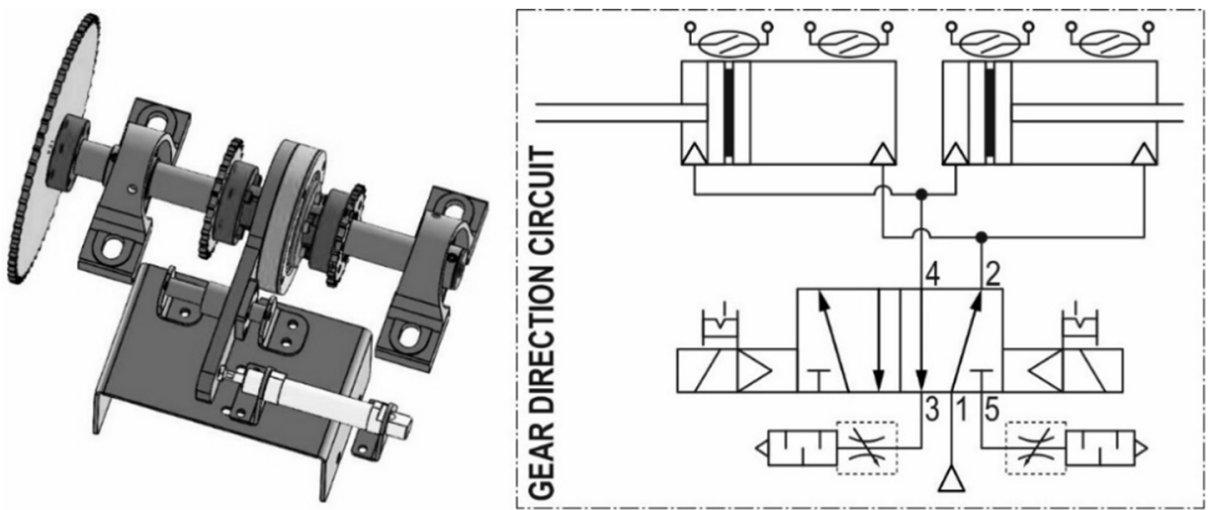

Fig. 5. Simple two-speed gearbox [4]

For the second vehicle, a commercial variator called NuVinci was used [7], Fig. 6.

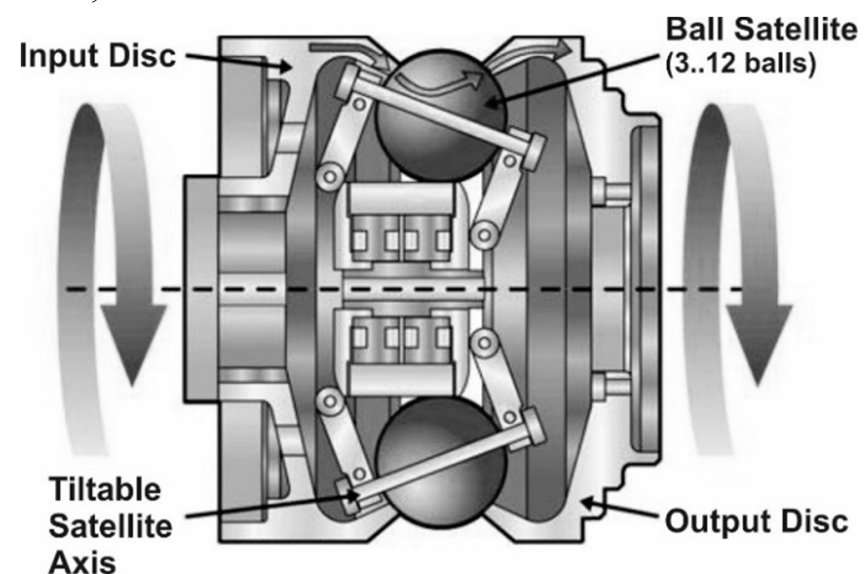

Fig. 6. NuVinci variator principle [7], modified by the author

However, its use was not a suitable solution (it could not eliminate torque peaks from the engine). 
TECHNICAL SCIENCES AND TECHNOLOGIES

The third vehicle has in the design a four-speed gearbox controlled by four single-acting pneumatic cylinders, Fig. 7.
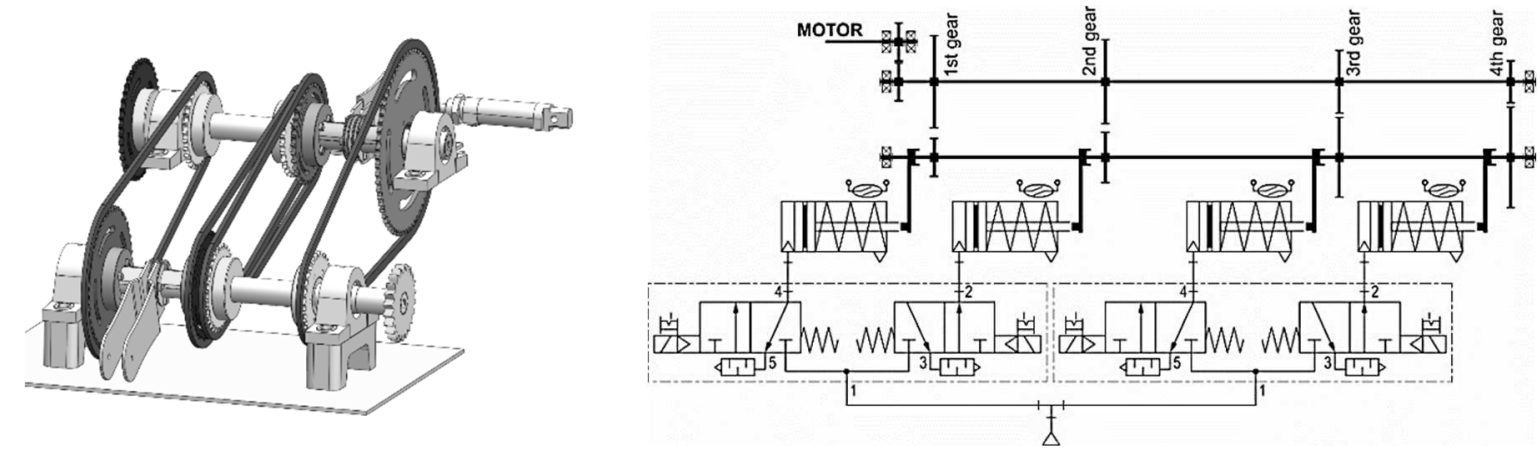

Fig. 7. Four-speed gearbox [5]

\section{Differential}

In the case of the first vehicle, a differential was not required, as it was a three-wheeled version of the vehicle with a wheelbase: two at the front without a drive, one driven at the rear.

In the case of the other two vehicles, a simple differential made by modifying the industrial idlers was used, Fig. 8 [4;9].

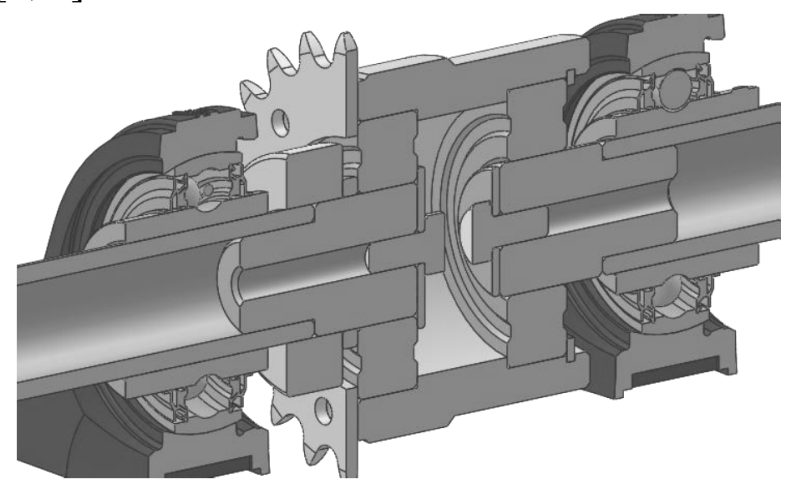

Fig. 8. Simple differential [4]

Conclusions. From the results so far in the competition Aventics/Emerson PNEUMOBILE Competition race can be drawn the following conclusions:

1. On vehicle No. 2 to replace the NuVinci gearbox with a more reliable variant and to test it for individual parameters.

2. Complete and thoroughly test the third vehicle.

3 . Evaluate the degree of change of the concept and replacement of unsuitable components on the monitored parameters.

Up to participation in the announced races on time May 13-15, 2021, Eger will show how much the parameters of the registered vehicles have been improved.

Acknowledgement. This article was created thanks to the KEGA project support: 010TUKE-4/2020 - Implementation of new knowledge and innovative approaches to the process of teaching robotics in line with Industry 4.

This article was created thanks to the project support: Research modules for intelligent robotic systems (ITMS: 26220220141) supported by the Research \& Development operational Program funded by the ERDF.

\section{References}

1. Aventics Hungary Kft.: Announcement and rules, XIII. International Aventics Pneumobile Competition 2020 - powered by Emerson, Available on the Internet: http://en.pneumobil.hu/ pneumobile_2020/announcement_and_rules/announcement_and_rules_2020. 
2. Demko, M., Tuleja P.: Analyza hnacej sustavy pre vozidlo pohaňane stlačenym vzduchom (Analysis of drive system for a vehicle powered by compressed air). Bachelor thesis. Technical university of Košice, Košice 2018, 50 pp., (in Slovak).

3. Hajduk, M., Tuleja, P.: ZAKLADY PNEUMATICKYCH MECHANIZMOV I.: Vyroba, úprava a rozvod stlačeneho vzduchu a vákua, Technická univerzita v Košiciach, Košice 2013, ISBN 978-80-553-1605-5, (in Slovak).

4. Palko, M., Tuleja, P.: Navrh experimentalneho vozidla pohaňaneho stlačenym vzduchom (Design of an experimental compressed air powered vehicle). Diploma thesis. Technical university of Košice, Košice 2018, 70 pp., (in Slovak).

5. Premkumar, M. A., Palko, M.: Design of Gearbox and Differential of a vehicle for Pneumobile 2020 Project, Bachelor thesis. Technical university of Košice, Košice 2020, 71 pp., (in English).

6. Profile cylinder ISO 15552, Series PRA, Datasheet. Available on the Internet: https://www.aventics.com/pneumatics-catalog/Configuration/?Language $=$ en \&

Variant=internet\&file=en/pdf/PDF_p8771_en.pdf.

7. road.cc. NuVinci: no gears, but all the gears you need?. [online]:

$<$ https://road.cc/content/feature/5664-nuvinci-no-gears-all-gears-you-need $>$

8. Shaimardanov, A.-S., Tuleja, P.: Design of Energy-saving Pneumatic Drive for Pneumobile Project, Bachelor thesis. Technical university of Košice, Košice 2020, 47 pp., (in English).

9. Solárik, R., Jánoš, R.: Návrh motora pre pneumobil 2019 (Design of Engine for Pneumobile 2019), Bachelor thesis. Technical university of Košice, Košice 2019, 71 pp., (in Slovak).

10. https://en.pneumobil.hu/results/results_2019/detailed_results/

11. https://en.pneumobil.hu/results/results_2018/detailed_results/

UDC (07)621.7,621.8

\section{Петер Тулея}

\section{АНАЛІЗ ІСНУЮЧИХ РІШЕНЬ ПРИВОДНИХ БЛОКІВ ДЛЯ ПНЕВМОБІЛЬНОГО ПРОЕКТУ}

Актуальність теми дослідження. Сьогодні в автомобільній промисловості існує потреба у створенні альтернативних методів пересування. Стиснене повітря - одна з альтернатив викопному паливу.

Постановка проблеми. Щоб перевірити можливості використання стисненого повітря в якості енергії для приведення в рух транспортних засобів, організовується конкурс, на якому представлені команди європейських університетів під егідою компанії, що виробляє пневматичні компоненти. Ми, працівники Інституту автоматики, мехатроніки, виробничих технологій і робототехніки, також двічі брали участь у иьому конкурсі. Підсумки конкурсу, доповнені презентацією ще не реалізованого автомобіля, є предметом иієї статті.

Аналіз останніх досліджень і публікацій. Оскільки ие аналіз досягнутих результатів, у статті розглядаються иляхи їх досягнення, а не методи наукового характеру.

Виділення недосліджених частин загальної проблеми. Оскільки це оиінка досягнутих результатів, в статті не розглядаються конкретні проблеми теоретичної області. Результати представлені читачеві для ознайомлення $i$ залишають місче для його власної очінки.

Постановка завдання. Мета статті - ознайомити громадськість з результатами дослідження і способами їх досягнення. Це також свого роду запрошення для потенційного співробітництва людей, які цікавляться ицим питанням.

Виклад основного матеріалу. Основою для створення статті послужили відомості зі студентських робіт, результатами яких були описані автомобілі.

Висновки відповідно до статті. Висновки до статті показують проблеми, які мають бути вирішені для подальшого продовження проекту, якщчо можливо, з іншими «ентузіастами» в иій галузі, щео використовують стиснене повітря для нетрадииійних иілей.

Ключові слова: проєкт пневмобіля; аналіз; параметри пневмодвигуна; пневматичні компоненти.

Рис.: 8. Табл.: 4. Бібл.: 11.

Tuleja Peter - Eng., PhD, Assistant Professor, Technical university in Kosice, Faculty of Mechanical Engineering, Institute of Automatization, Mechatronics, Robotics and Production Systems, Department of Production Systems and Robotics (Komenskeho Park 8, 04200 Kosice, Slovakia).

E-mail: peter.tuleja@tuke.sk

Scopus Author ID: 55570858300

Tuleja, P. (2020). Analysis of existing drive unit solutions for the pneumobile project. Technical sciences and technologies, 3(21), pp. 129-134. 